\title{
Analisis Jumlah Wajib Pajak Pph OP Yang Tidak Menyampaikan SPT Dengan Penerimaan Pajak Pada KPP Pratama Jakarta Duren Sawit
}

\author{
Dede Suleman \\ Universitas Bina Sarana Informatika \\ Fakultas Ekonomi dan Bisnis \\ Dede.dln@bsi.ac.id
}

(Suleman, 2019a)

Suleman, D. (2019a). Analisis Jumlah Wajib Pajak Pph OP Yang Tidak Menyampaikan SPT Dengan Penerimaan Pajak Pada KPP Pratama Jakarta Duren Sawit. Moneter, 6(2), 173-178.

\begin{abstract}
Tax is a mandatory contribution to the state one of which is a personal income tax which is one of the most potential tax revenues. In this study, it will give an idea of how the percentage of taxpayers who did not submit a tax return compared to the percentage of income tax income Op. The place of research in this study is the Jakarta Duren Sawit Tax Office. The results show that the number of taxpayers who do not send annual tax returns declined in 2017 to only 9.4\% of taxpayers who did not send tax returns, this shows that taxpayers began to realize to submit their tax returns every year. The amount of tax revenue from personal income tax turned out to show the results that each year has increased especially in 2017 compared to 2016 which experienced an increase of $72 \%$ and the largest income occurred in 2017 at $89 \%$ of the target set.
\end{abstract}

Keywords: PPh OP, Target, penerimaan pajak, SPT

\section{PENDAHULUAN}

Pendapatan negara salah satunya bersumber dari penerimaan pajak. Pajak tersebut akan digunakan untuk membiayai pembangunan dan meningkatkan kesejahteraan seluruh rakyat Indonesia. Salah satu penerimaaan pajak berasal dari pajak penghasilan yang terbagi menjadi dua, yaitu yang berasal dari Wajib Pajak orang pribadi dan badan.

Upaya untuk tercapainya penerimaan pajak diharapkan kepada seluruh Wajib Pajak dapat menunaikan kewajiban sebagai warga negara dengan mengisi SPT (Surat Pemberitahuan) yang dilandasi kejujuran dan menyampaikannya sesuai jadwal yang telah ditentukan. Karena masalah kepatuhan wajib pajak termasuk masalah yang penting agar bisa ikut berkontribusi terhadap kemajuan bangsa.

Saat Wajib Pajak tidak patuh maka akan menimbulkan keinginan untuk melakukan tindakan penghindaran, pengelakan, penyelundupan, dan pelalaian pajak yang pada akhirnya tindakan tersebut akan menyebabkan penerimaan pajak negara akan berkurang dan tidak sesuai target yang telah ditetapkan.

Melihat dari data didapati bahwa tingkat kepatuhan dan penerimaan pajak khususnya pada KPP Pratama
Jakarta Duren Sawit tidak sepenuhnya wajib pajak patuh untuk melakukan kewajiban perpajakannya, padahal dengan jumlah Wajib Pajak yang patuh akan mengoptimalkan tingkat kepatuhan wajib pajaknya dan dapat meningkatkan target dan realisasi penerimaan negara dari sektor pajak.

Ketidakpatuhan biasanya timbul apabila Wajib Pajak tidak mempunyai pengetahuan dan pemahaman perpajakan yang memadai sehingga Wajib Pajak secara tidak sengaja tidak melakukan kewajiban perpajakannya, seperti tidak mendaftarkan diri untuk memperoleh Nomor Pokok Wajib Pajak (NPWP) dan tidak melaporkan Surat Pemberitahuan (SPT) atau para Wajib Pajak melalukan kewajiban perpajakan tetapi tidak sepenuhnya benar, seperti tidak membayar dan melaporkan pajak tidak sesuai dengan tarif pajak yang berlaku (Mulyanti, D. \& Sugiharty, 2016)

Pemerintah telah melakukan reformasi pada undangundang perpajakan. Terutama pada pajak pengahasilan itu sendiri yang telah mengalami reformasi undang-undang mulai dari tahun 1084 dan tahun 2000 dan yang terakhir apda tahun 2008. Reformasi ini dilakukan untuk mempermudah dan menyederhanakan perhitungan pajak dan pembebanan pajak yang dikondisikan dengan Wajib pajak. Reformasi dalam perpajakan terus dilakukan 
pemerintah da;am hal perumusan dan pembuatan atauran dan Undang-Undang dan penyempurnaan administrasi perpajakan yang memudahkan

Kepatuhan memenuhi kewajiban perpajakan merupakan tanggungjawab warga negara sebagai Wajib Pajak, yang punya kewajiban dalam hal membayar dan melaporkan pajak harus secara akurat dan tepat waktu agar Wajib Pajak tidak dikenakan sanksi atas keterlambatan pelaporan tersebut.

Semakin besar kesadaran Wajib Pajak tentang pentingnya kepatuhan perpajakan, maka akan semakin besar pula penerimaan pajak yang akan diperoleh oleh negara. Jika penerimaan negara meningkat, maka kesejahteraan seluruh rakyat Indonesia pun juga akan meningkat.

Sehingga dalam penelitian ini ingin mengetahui berapa prosentase Wajib Pajak yang tidak melaporkan SPT nya dengan selisis dari target penerimaan Pajak. Dengan data jumlah SPT tahunan penerimaan pajak orang pribadi periode tahun 20132017.

\section{Pengertian Pajak}

Pajak (Inggris, Tax) adalah iuran wajib dari rakyat kepada negara dengan tidak menerima imbalan jasa secara langsung berdasarkan undang-undang, untuk membiayai pengeluaran-pengeluaran umum. Oleh karena itu, pajak merupakan salah satu sumber penerimaan negara sehingga pemungutannya dapat dipaksakan, baik secara perseorangan maupun dalam bentuk badan usaha. Adapun yang dimaksud dengan tidak menerima imbalan jasa secara langsung adalah imbalan khusus yang erat hubungannya dengan pembayaran iuran tersebut. Imbalan jasa dari negara antara lain menggunakan jalan-jalan, perlindungan dari pihak keamanan, pembangunan jembatan yang tidak ada hubungannya langsung dengan pembayaran itu (masdiasmi,2011)

(Rahayu, 2017), "Kesadaran wajib pajak adalah kondisi dimana wajib pajak mengerti dan memahami arti, fungsi maupun tujuan pembayaran pajak kepada negara". Dengan kesadaran wajib pajak yang tinggi akan memberikan pengaruh kepada meningkatnya kepatuhan pajak yang lebih baik lagi.

Tingginya tingkat kesadaran wajib pajak dapat diihat dari Target penerimaan pajak tercapai.
a. Tingkat kepatuhan pajak tinggi.
b. Tax ratio tinggi.
c. Jumlah wajib pajak meningkat sejalan dengan
d. jumlah masyarakat usia produktif.
e. Jumlah tagihan pajak rendah.
f. Tingkat pelanggaran rendah.

Pajak adalah iuran kepada negara (yang dapat dipaksakan) yang terutang oleh yang wajib membayarnya menurut peraturan-peraturan, dengan tidak mendapatkan prestasi kembali, yang langsung dapat ditunjuk, dan yang gunanya adalah untuk membiayai pengeluaran-pengeluaran umum berhubungan dengan tugas negara yang menyelenggarakan pemerintahan (waluyo dalam (Suleman, 2018)

Menurut (Resmi, dalam (Suleman, 2019b)) ciri-ciri pajak yang melekat pada definisi pajak :

a. Pajak dipungut berdasarkan atau dengan kekuatan undang-undang serta aturan pelaksanannya.

b. Dalam pembayaran pajak tidak dapat ditunjukan adanya kontraprestasi undividual oleh pemerintah.

c. Pajak di pungut oleh Negara, baik pemerintah pusat maupun pemerintah daerah.

d. Pajak diperuntukan bagi pengeluaranpengeluaran pemerintah yang bila dari pemasukannya masih dapat surplus, digunakan untuk membiayaan public investment.

Ciri-ciri pajak adalah sebagai berikut menurut Suandy dalam (Suleman, 2019b):

a. Pajak merupakan peralihan kekayaan dari orang atau badan ke pemerintah.

b. Pajak dipungut berdasarkan atau dengan kekuatan undang-undang serta aturan pelaksanaannya, sehingga dapat dipaksakan.

c. Dalam pembayaran pajak tidak dapat ditunjukkan adanya kontraprestasi langsung secara individual yang diberikan oleh pemerintah.

d. Pajak dipungut oleh negara baik oleh pemerintah pusat maupun pemerintah daerah.

e. Pajak diperuntukkan bagi pengeluaranpengeluaran pemerintah yang bila dari pemasukannya masih terdapat surplus, dan dipergunakan untuk membiayai public investment.

f. Pajak dapat digunakan sebagai alat untuk mencapai tujuan tertentu dari pemerintah.

g. Pajak dapat dipungut secara langsung atau tidak langsung

Fungsi pajak menurut (Diana dalam (Suleman, 2019b)) memiliki dua fungsi utama, diantaranya :

a. Fungsi penerimaan (budgeter) Yaitu sebagai alat (sumber untuk memasukan uang sebanyakbanyaknya dalam kas Negara dengan tujuan membiayai pengeluaran Negara yaitu pengeluaran rutin dan pembangunan. Sebagai sumber pendapatan Negara pajak berfungsi untuk membiayai pengeluaran-pengeluaran Negara

b. Fungsi Mengatur (regulerend) Sebagai fungsi alat untuk mencapai tujuan tertentu dibidang keuangan (bidang ekonomi, politik,budaya,pertahanan keamanan). 
Menurut (masdiasmo, 2016) Jenis Pajak Jenis Pajak

a. Pajak Menurut Golongan

1) Pajak Langsung (Direct Tax) Pajak langsung adalah pajak yang dikenakan secara berkala pada Wajib Pajak berdasarkan Surat Ketatapan Pajak (SKP) yang dibuat oleh kantor pajak. Pada intinya, Surat Ketetapan Pajak (SKP) memuat berapa besar pajak yang harus dibayar Wajib Pajak. Pajak langsung harus dipikul sendiri oleh si Wajib Pajak, sebab pajak ini tidak bisa dialihkan kepada pihak lain, berbeda dengan pajak yang tidak langsung yang bebannya bisa dialihkan kepad pihak lain. Contoh pajak langsung yaitu Pajak Penghasilan dan PBB (Pajak Bumi dan Bangunan)

2) Pajak Tidak Langsung (Indirect Tax) Pajak tidak langsung adalah pajak yang dikenakan pada Wajib Pajak hanya jika Wajib Pajak melakukan perbuatan atau peristiwa tertentu. Oleh karena itu, pajak tidak langsung tidak bisa dipungut secara berkala, pajak hanya bisa dipungut jika terjadi perbuatan atau peristiwa tertentu yang menimbulkan kewajiban membayar pajak. Contoh pajak tidak langsung yaitu, Pajak Penjualan atas Barang Mewah. Pajak ini bisa dikenakan, jika ada Wajib Pajak yang melakukan penjaulan barang mewah.

b. Pajak Menurut Sifatnya

1) Pajak Subjektif Pajak subjektif adalah pajak yang pemungutannya berdasar atas subjeknya (orangnya), di mana keadaan diri pajak dapat mempengaruhi jumlah yang harus dibayar. Contoh: Pajak Penghasilan dan Pajak Kekayaan.

2) Pajak Objektif Pajak objektif adalah pajak yang pemungutannya berdasarkan atas objeknya. Contoh: Pajak Kekayaan, Bea Masuk, Bea Meterai, Pajak Impor, Pajak Kendaraan Bermotor, Pajak Bumi dan Bangunan, dan sebagainya.

c. Pajak Menurut Pemungutannya

1) Pajak Negara (Pusat) Pajak Negara adalah pajak yang dipungut oleh Pemerintah Pusat melalui aparatnya, yaitu Dirjen Pajak, Kantor Inspeksi Pajak yang tersebar di seluruh Indonesia, maupun Dirjen Bea dan Cukai. Contoh: Pajak Penghasilan, Pajak Pertambahan Nilai, Pajak Penjualan atas Barang Mewah, Pajak Bumi dan Bangunan, Bea Perolehan Hak atas Tanah dan Bangunan, dan Bea Meterai

2) Pajak Daerah (Lokal) Pajak Daerah (lokal) adalah pajak yang dipungut oleh Pemerintah Daerah dan terbatas pada rakyat daerah itu sendiri, baik yang dilakukan oleh Pemda Tingkat I maupun Pemda Tingkat II. Contoh: Pajak Radio, Pajak Televisi, Pajak
Hotel, Pajak Restoran, Pajak Hiburan dan Pajak Sarang Burung Walet.

Pengertian Pajak Penghasilan adalah pajak yang terhutang sehubungan dengan pekerjaan, jasa dan kegiatan yang wajib dipotong dan disetorkan oleh pemberi kerja menurut (Rahayu, 2017).

Pajak atas penghasilan berupa gaji, upah, honorarium, tunjangan, dan dalam bentuk apapun sehubungan dengan pekerjaan atau jabatan, jasa dan kegiatan yang dilakukan oleh orang pribadi subjek dalam negeri sebagaimana yang dimaksud dalam Pasal 21 UndangUndang No.36 Tahun 2008 tentang Pajak Penghasilan

\section{Pengertian Kepatuhan Pajak}

Menurut (Rahayu, 2017), "Kepatuhan perpajakan merupakan ketaatan wajib pajak dalam melaksanakan ketentuan Perpajakan yang berlaku, sedangkan wajib pajak yang patuh adalah wajib pajak yang taat memenuhi kewajiban perpajakan sesuai dengan ketentuan Peraturan Perundang-undangan”.

kepatuhan perpajakan dibagi menjadi:

a. Kepatuhan pajak formal adalah Kepatuhan perpajakan formal merupakan ketaatan Wajib Pajak dalam memenuhi Ketentuan formal perpajakan. Ketentuan formal ini terdiri dari:

1) Tepat waktu dalam mendaftarkan diri untuk memperoleh NPWP maupun untuk ditetapkan memperoleh NPWP.

2) Tepat waktu dalam menyetorkan pajak yang terutang.

3) Tepat waktu dalam melaporkan pajak.

b. Kepatuhan Perpajakan Material adalah Kepatuhan perpajakan material merupakan ketaatan wajib pajak dalam memenuhi ketentuan material perpajakan. Ketentuan material terdiri dari:

1) Tepat dalam menghitung pajak terutang sesuai dengan peraturan perpajakan.

2) Tepat dalam memperhitungkan pajak terutang sesuai dengan peraturan perpajakan.

3) Tepat dalam memotong maupun memungut pajak (wajib pajak sebagai pihak ketiga).

Kepatuhan Wajib Pajak dipengaruhi oleh beberapa faktor yaitu:

a. Kondisi sistem administrasi perpajakan suatu negara. Sistem administrasi perpajakan suatu negara akan efektif apabila didukung oleh instansi pajak yang efektif, sumber daya pegawai pajak yang mumpuni, dan prosedur perpajakan yang baik pula.

b. Kualitas pelayanan perpajakan yang diberikan kepada Wajib Pajak. Dengan sistem administrasi perpajakan yang efektif akan memberikan dampak pada peningkatan kualitas pelayanan pajak yang diberikan instansi pajak 
kepada wajib pajak, sehingga wajib pajak rela untuk membayar pajak kepada negara tanpa mengharapkan imbalan secara langsung.

c. Kualitas penegakan hukum perpajakan adalah kepatuhan perpajakan dapat ditingkatkan melalui tekanan kepada wajib pajak untuk tidak melakukan pelanggaran atau tindakan ilegal dalam usahanya untuk menyeludupkan pajak. Pemberian sanksi perpajakan merupakan salah satu pelaksanaan pada wajib pajak agar wajib pajak tidak lagi melakukan pelanggaran perpajakan.

d. Kualitas pemeriksaan pajak dimana kualitas pemeriksaan pajak ditentukan dengan kompetensi pemeriksa, keahlian pemeriksa, independensi pemeriksa, maupun integritas pemeriksa yang baik. Pemeriksa dikatakan berkualitas apabila setiap tahapan pemeriksaan dilakukan sesuai prosedur, sehingga menghasilkan ketetapan pajak yang berkualitas. Ketetapan pajak yang berkualitas merupakan ketetapan yang diterima dengan baik oleh wajib pajak. Apabila ketetapan pajak yang dihasilkan pemeriksaan adalah kurang bayar dan hasil pemeriksaan ini diterima oleh wajib pajak maka tagihan pajak dalam ketetapan tersebut dapat direalisasikan untuk dibayar kepada negara, pada akhirnya penerimaan negara pun akan bertambah.

e. Tinggi rendahnya tarif pajak yang ditetapkan ialah disisi lain negara membutuhkan penerimaan pajak sesuai dengan target yang telah ditetapkan untuk menjalankan fungsi pemerintahan.

f. Kemauan dan kesadaran Wajib Pajak dimana kemauan dan kesadaran wajib pajak akan memberikan pemahaman tentang arti, dan tujuan pembayaran pajak yang diberikan kepada Negara. Sehingga apabila kemauan dan kesadaran wajib pajak tinggi akan memberikan dampak kepada kepatuhan perpajakan yang lebih baik lagi, sehingga penerimaan pajak diharapkan dapat mencapai target yang telat ditetapkan.

\section{Pengertian SPT}

Surat Pemberitahuan (SPT) adalah surat yang oleh wajib pajak digunakan untuk melaporkan penghitungan dan/atau pembayaran pajak, objek pajak dan/atau bukan objek pajak, dan/atau harta dan kewajiban sesuai dengan ketentuan peraturan perundang-undangan perpajakan menurut (masdiasmo, 2016)

SPT memiliki beberapa fungsi menurut (Negara, 2017) sebagai berikut :

a. Sebagai sarana melaporkan, melaksanakan, dan mempertanggungjawabkan perhitungan pajak yang sebenarnya terutang. b. Sebagai laporan tentang pembayaran pajak yang telah dilaksanakan sendiri oleh wajib pajak dalam satu tahun pajak atau bagian tahun pajak.

c. Sebagai laporan pembayaran dari pemotong atau pemungut tentang pemotongan pemungut pajak orang pribadi atau badan lain. Merupakan alat penelitian atas kebenaran perhitungan pajak yang terutang.

Secara garis besar Surat Pemberitahuan (SPT) dibedakan menjadi yaitu: Surat Pemberitahuan (SPT) masa adalah surat yang oleh wajib pajak digunakan untuk melaporkan perhitungan dan/atau pembayaran pajak terutang dalam suatu masa pajak atau bagian dalam 1 (satu) tahun dan Surat Pemberitahuan (SPT) tahunan adalah surat yang oleh wajib pajak digunakan untuk melaporkan perhitungan dan pembayaran pajak yang terutang dalam suatu tahun pajak.

Menurut (masdiasmo, 2016) batas waktu penyampaian Surat Pemberitahuan adalah:

a. Untuk Surat Pemberitahuan Masa, paling lama 20 (dua puluh) hari setelah akhir Masa Pajak. Khusus untuk Surat Pemberitahuan Masa Pajak Pertambahan Nilai disampaikan paling lama akhir bulan berikutnya setelah berakhirnya masa pajak.

b. Untuk Surat Pemberitahuan Tahunan Pajak Penghasilan wajib pajak orang pribadi, paling lama 3 (tiga) bulan setelah akhir tahun pajak.

c. Untuk Surat Pemberitahuan Tahunan Pajak Penghasilan wajib pajak badan, paling lama 4 (empat) bulan setelah akhir tahun pajak.

\section{METODOLOGI PENELITIAN}

Obyek penelitian adalah KPP Pratam Jakarta Duren Sawit, Jakarta Timur, Metode penelitian ini menggunakan metode perbandingan serta studi pustaka yang bersumber dari sejumlah literatur yang meliputi referensi buku-buku yang dapat menunjang isi penulisan, kemudian sejumlah situs internet yang dapat menambah wahana keilmuan sebagai Data yang diolah adalah tahun 2015 -2017

\section{HASIL DAN PEMBAHASAN}

Hasil pembahasan akan diterangkan perbandingan data dari tahun ke tahun untuk Total Wajib pajak Pajak Pengahasilan Orang Pribadi (PPh OP) (yang menyampaikan SPT dan yang tidak menyampaikan) serta Target dan realisasi penerimaan pajak pada KPP Pratama Jakrta Duren sawit.

\section{WP Tidak Penyampaian SPT PPh OP}

Tabel 1 Daftar WP Tidak Penyampaian SPT PPh OP Tahun 2015-2017 (Jiwa)

\begin{tabular}{lllr}
\hline Tahun & Terdaftar & $\begin{array}{c}\text { Tidak } \\
\text { Menyampaikan }\end{array}$ & Prosentase \\
\hline 2015 & 80.099 & 25.645 & $32 \%$ \\
\hline 2016 & 86.651 & 22.873 & $26.4 \%$ \\
\hline
\end{tabular}




\begin{tabular}{rrrr}
\hline 2017 & 86.067 & 8.056 & $9.4 \%$ \\
\hline
\end{tabular}

Sumber: Hasil olah data 2019

Menyusun tabel analisis Wajib Pajak tidak Menyampaikan SPT PPh OP yaitu dengan metode perbandingan antara WP Tidak menyampaiakan dan WP terdaftar pada tahun 2015-2017, Rumus yang digunakan adalah :

$$
\begin{gathered}
\text { Tahun } 2015=\frac{W P \text { PPh OP Tidak Menyampaikan }}{\text { WP PPh OP Terdaftar }} \times 100 \% \\
\text { Tahun } 2015=\frac{25.645}{80.099} \times 100 \%=32 \%
\end{gathered}
$$

Pada tahun 2015, prosentase Wajib Pajak PPh OP yang tidak menyampaikan SPT di KPP Pratama Jakarta Duren Sawit sebesar 32\% . Jika dilihat dari data tahun 2015 merupakan tahun yang terbesar WP PPh OP tidak menyampaikan SPT.

$$
\begin{gathered}
\text { Tahun } 2016=\frac{W P \text { PPh OP Tidak Menyampaikan }}{\text { WP PPh OP Terdaftar }} \times 100 \% \\
\text { Tahun } 2016 \frac{22.873}{86.651} \times 100 \%=26.4 \%
\end{gathered}
$$

Pada tahun 2016, prosentase Wajib Pajak PPh OP yang tidak menyampaikan SPT di KPP Pratama Jakarta Duren Sawit hanya sebesar 9,4\% turun drastic dari 2 tahun sebelumnya. Jika dibandingkan dengan tahun 2015 ada selisih 2.772 jiwa Wajib Pajak PPh OP yang menyampaikan SPT atau sama dengan prosentase selisih $5,6 \%$

$$
\begin{gathered}
\text { Tahun } 2017=\frac{\text { WP PPh OP Tidak Menyampaikan }}{\text { WP PPh OP Terdaftar }} \times 100 \% \\
\text { Tahun } 2017 \frac{8.056}{86.067} \times 100 \%=9.4 \%
\end{gathered}
$$

Pada tahun 2017, prosentase Wajib Pajak PPh OP yang tidak menyampaikan SPT di KPP Pratama Jakarta Duren Sawit sebesar 26.4\%. Jika dibandingkan dengan tahun 2016 ada selisih 14.817 jiwa Wajib Pajak PPh OP yang menyampaikan SPT bisa dikatakan meningkat WP yang menyampaikan SPT sebesar 17\% dari tahun 2016.

\section{Data WP PPh OP Tidak Menyampaikan Terhadap Realisasi Penerimaan Pajak}

Tabel 2. Target dan Penerimaan PPh Op

\begin{tabular}{cccc}
\hline Tahun & $\begin{array}{c}\text { Target Pajak } \\
(\mathrm{Rp})\end{array}$ & $\begin{array}{c}\text { Realisasi Pajak } \\
(\mathrm{Rp})\end{array}$ & $\begin{array}{c}\text { Prosentase } \\
(\%)\end{array}$ \\
\hline 2015 & 318.869 .596 .946 & 271.294 .523 .643 & $85 \%$ \\
\hline 2016 & 611.956 .572 .906 & 498.234 .262 .011 & $81 \%$ \\
\hline 2017 & 768.869 .404 .940 & 688.035 .703 .646 & $89 \%$ \\
\hline \multicolumn{4}{l}{ Sumber: Hasil olah data 2019 }
\end{tabular}

Dapat Disimpulkan dari Tabel 2 bahwa target dan realisasi penerimaan pajak PPh OP di KPP pratama Jakarta Duren Sawit setiap tahun tidak mencapai target penerimaan yang telah ditetapkan karena prosentase realisasi hanya menunjukan angka sekitar 89\% persen yang tertinggi di tahun 2017

$$
\text { Tahun } 2015=\frac{\text { Reaalisasi }}{\text { Target }} \times 100 \%
$$

$$
\text { Tahun } 2015=\frac{271.294 .523 .643}{318.869 .596 .946} \times 100 \%=85 \%
$$

Pada tahun 2015 Target penerimaan terhadap Realisasi penerimaan pajak PPh Op hanya mencapai $85 \%$ dari target yang di tetapkan.

$$
\begin{aligned}
& \text { Tahun } 2016=\frac{\text { Reaalisasi }}{\text { Target }} \times 100 \% \\
& \text { Tahun } 2016=\frac{498.234 .262 .011}{611.956 .572 .906} \times 100=81 \%
\end{aligned}
$$

Pada tahun 2016 Target penerimaan terhadap Realisasi penerimaan pajak PPh Op hanya mencapai $81 \%$ dari target yang di tetapkan. Namun jika di lihat jumlah nya dengan 2015 penerimaan meningkat jumlah nya sebesar $54 \%$.

$$
\begin{aligned}
& \text { Tahun } 2017=\frac{\text { Reaalisasi }}{\text { Target }} \times 100 \% \\
& \text { Tahun } 2017=\frac{688.035 .703 .646}{768.869 .404 .940} \times 100=81 \%
\end{aligned}
$$

Pada tahun 2017 Target penerimaan terhadap Realisasi penerimaan pajak PPh Op hanya mencapai $89 \%$ dari target yang di tetapkan ini merupakan angka prosentase tertinggi selama periode 3 tahun . Namun jika di lihat jumlah nya dengan 2016 penerimaan meningkat jumlah nya sebesar $72 \%$.

\section{KESIMPULAN}

Wajib Pajak PPh OP yang menyampaikan SPT tidak tahun nya mengalami penurunan prosentase dan jumlah artinya bahwa setiap tahun masyarakat mulai sadar untuk melaporkan SPT PPh OP. Penurunan ini sangat drastis tiap tahunnya dan sampai 2016 hanya sekitar $9.4 \%$ saja yang tidak menyampaikan selebih nya menyampaikan SPT nya .

Penerimaan PPh OP tiap tahunnya memang tidak bisa mencapai $100 \%$ dari target yang telah ditetapkan namun bisa dikatakan bahwa jumlah kenaikan penerimaan pajak PPh OP mengalami peningkatan 
prosentase lebih dari 54\% dari tahun 2015 ke 2016

dan juga sampai $72 \%$ dari tahun 2016 ke 2017.

\section{REFERENSI}

Masdiasmo. (2011). Perpajakan 2011. yogyakarta: CV.ANDI.

masdiasmo. (2016). Perpajakan Edisi Terbaru 2016. yogyakarta: CV.ANDI.

Mulyanti, D., \& Sugiharty, F. S. (2016). Efektifitas wpop dan tingkat kepatuhan menyampaikan spt terhadap penerimaan pajak penghasilan. Ecodemica, IV(2),(IV(2),), pp, 250-258.

Negara, T. A. S. (2017). Ilmu Hukum Pajak. Malang: Setara Press.

Rahayu, siti kurnia. (2017). Perpajakan (Konsep dan Aspek Formal). Bandung: Rekayasa Sains.

Suleman, D. (2018). Kontribusi Pemungutan Bea Perolehan Hak atas Tanah dan Bangunan (BPHTB) Terhadap Pendapatan Asli Daerah (PAD) di Kabupaten Bogor. Moneter, Volume 5(No.2 Oktober 2018), pp. 1-6.

Suleman, D. (2019a). Analisis Jumlah Wajib Pajak Pph OP Yang Tidak Menyampaikan SPT Dengan Penerimaan Pajak Pada KPP Pratama Jakarta Duren Sawit. Moneter, 6(2), 173-178.

Suleman, D. (2019b). Peran Pajak Restoran Terhadap Penerimaan Daerah Administrasi Jakarta Timur. Moneter, 6(1)(1 April 2019), pp. 7-12. waluyo. (2011). Perpajakan Indonesia 2011. Jakarta: Salemba Empat

\section{PROFIL PENULIS}

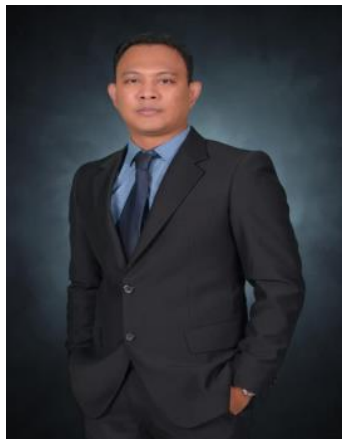

Dede Suleman adalah Doktor (c) Manajemen Marketing dari Universitas Mercubuana, Jakarta. Gelar Sarjana didapat dari dari Universitas Azzahra, jurusan Ekonomi, dan gelar Magister dari Universitas BSI Bandung.

Dede Suleman mengawali karier sebagai profesional di bidang ekspor dan import, kemudian sejak 2007 mulai menggeluti usaha di bidang Restaurant dengan mendirikan merk My Bento yang merupakan restaurant jaringan yang menyajikan menu makanan jepang siap saji. Saat ini menjabat sebagai Business Expansion Director. Dede Suleman juga berkarier sebagai Dosen tetap di Universitas Bina Sarana Informatika sejak Tahun 2011 banyak kontribusinya pada penulisan dalam skala nasional maupun Internasional berreputasi dengan tema penelitiannya ditema operasional waralaba ,manajemen keuangan, pemasaran dan perilaku konsumen, e-business, emarketing dan e-commerce dan marketing 4.0 